The Agriculturists 16(2):115-122(2018) ISSN 2304-7321 (Online), ISSN 1729-5211 (Print)

A Scientific Journal of Krishi Foundation

Indexed Journal

DOI: http://dx.doi.org/ 10.3329/agric.v16i02.40349

Impact Factor: 0.568 (GIF, 2015)

\title{
Determination of Crop Co-efficient Values for Jute (Corchorus olitorius L.)
}

\author{
A. J. Milla ${ }^{1}$, A. R. Akanda ${ }^{1}$, S. K. Biswas ${ }^{1}$ and M. A. Uddin ${ }^{2}$ \\ ${ }^{1}$ Irrigation and Water Management Division, Bangladesh Agricultural Research Institute (BARI), \\ Gazipur-1701, Bangladesh; ${ }^{2}$ Bangladesh Jute Research Institute, Dhaka, Bangladesh \\ *Corresponding author and Email: afrinbau@gmail.com
}

Received: 26 March 2017 Accepted: 25 December 2018

\begin{abstract}
Site specific calibration of crop coefficient $\left(\mathrm{K}_{\mathrm{c}}\right)$ values is essential for irrigation scheduling of any crop. In order to determine the values of $\mathrm{K}_{\mathrm{c}}$ for jute, an experiment was conducted at the Irrigation and Water Management Division of Bangladesh Agricultural Research Institute (BARI), Gazipur. An improved jute variety BJRI Tosa-2 (O-9897) was used in this experiment. The study examined growth and yield of the jute in terms of four irrigation treatments distributed over 7-28 days intervals. The treatments were so designed that drainage was allowed between the consecutive irrigations. Irrigation at 14days interval produced the highest dry fiber yield (3.93 t/ha) and was considered to be suitable for estimating seasonal crop evapotranspiration and $\mathrm{K}_{\mathrm{c}}$ values. The seasonal crop ET was $549.13 \mathrm{~mm}$ under this treatment. The $\mathrm{K}_{\mathrm{c}}$ values of jute at initial, development, mid-season and late season stages were found to be $0.72,1.39,1.26$ and 0.46 , respectively. As there is no FAO-recommended $\mathrm{K}_{\mathrm{c}}$ value for this crop, this locally calibrated values can be used for similar climatic conditions of Bangladesh and elsewhere. Therefore, based on $\mathrm{K}_{\mathrm{c}}$ value, it can be recommended that jute can be irrigated by equal amount of water needed for crop evapotranspiration $\left(\mathrm{ET}_{\mathrm{c}}\right)$ for different growth stages $(141.05,142.57$, 167.34 , and $84.30 \mathrm{~mm}$ ) to get maximum dry fiber yield.
\end{abstract}

Keywords: Reference evapotranspiration, crop evapotranspiration, micro-lysimeter, Penman-Monteith method.

\section{Introduction}

Jute (Corchorus olitorius) is an important crop of Bangladesh. It also goes by the name of "Golden Fiber" due to its golden brown colour and its importance as a cash crop. In terms of area and production, its position is first (0.67Mha and $2.03 \mathrm{t} / \mathrm{ha}$ ) among the other fiber crops of the country (BBS, 2014). In Bangladesh, jute is cultivated during the kharif season and water is an essential element if higher yield and quality of fiber is sought. Since jute cultivation is completely reliant on rainfall, irrigation scheduling was not a priority for the researchers of Bangladesh. However, recent changes in the rainfall pattern of the country has posed several risk factors that may cause severe damage to this industry. As a result, scientists are now interested in customizing the irrigation schedule for this crop in Bangladesh. In order to achieve this, crop co-efficient data is necessary, especially for regional water allocation plan for irrigation water. This research was therefore carried out to contribute towards this area of concern.

Crop coefficient $\left(\mathrm{K}_{\mathrm{c}}\right)$ value of jute is a prerequisite for accurate measurement of crop water 
requirement at different stages of growth. It is the ratio of Crop evapotranspiration $\left(\mathrm{ET}_{\mathrm{c}}\right)$ to the reference evapotranspiration $\left(\mathrm{ET}_{0}\right)$ of alfalfa grass. Crop coefficient values for a number of crops grown under different climatic conditions have been suggested by Doorenbos and Pruitt (1977). The values of $K_{c}$ changes with the growth stages of a crop. Several researchers (Pruitt et al., 1972; Jensen, 1974; Doorenbos and Pruitt, 1977; Burman et al., 1980; Wright, 1982; Pruitt et al., 1987) have devised experimental procedures for the determination of crop coefficient value. The values of $\mathrm{K}_{\mathrm{c}}$ also vary with location, cultivar, soil and weather conditions. Therefore, site specific determination of crop coefficient $\left(\mathrm{K}_{\mathrm{c}}\right)$ values is very important (Tyagi et al., 2000) for successful irrigation management of a crop. However, such information have not yet been surfaced for jute cultivation in the country. Although several agronomic experiments were conducted with jute in Bangladesh, none of them reported the crop coefficient values (Alam et al., 2011; Begum and Kumar, 2014; Nizam et al., 2015; Billah et al., 2016). This research aims to generate information towards fulfilling this research gap in the country.

Despite several efforts, a standard irrigation scheduling and water management technique for jute could not be developed in Bangladesh. Growers therefore, depend on the rainfall and their indigenous knowledge base. However, for better production of jute in the country, a proper irrigation schedule is absolutely necessary. In this regard, this research was carried out on Lysimeter to determine the crop coefficient values of jute at different growth stages, which can be used as a reference value for the country.

\section{Materials and Methods}

The experiments were conducted in a microlysimeter at the research farm of Bangladesh Agricultural Research Institute, Gazipur, during the summer season of 2016. It was a warm-dry climate, with average temperature of $30.73^{\circ} \mathrm{C}$. The average relative humidity, wind speed, and sunshine hour were $80 \%, 16 \mathrm{~km} / \mathrm{hr}$, and 5.37 , respectively. The highest rainfall was recorded in July (Table 1) and it was $42.11 \%$ of the total rainfall during the entire growing season. The soil of experimental field was silty clay loam, with field capacity and bulk density of $29.5 \%$ and $1.5 \mathrm{~g} / \mathrm{cm}^{3}$, respectively.

A hybrid jute variety (BJRI Tosa-2 (O9897))was selected for the lysimeter experiment. Seeds were sown in a $1 \mathrm{~m}^{2}$ micro-lysimeter at a spacing of $0.30 \mathrm{~m} \times 0.10 \mathrm{~m}$ on 18 April 2016 . Seeds were treated by using Vitavax $200(0.4 \%$ of seed weight) before sowing according to Islam et al. (2001). The same crop was also sown in field plots adjacent to the lysimeter tanks with the objective of creating favorable atmospheric condition (Figure 1).

Table 1. Mean monthly weather data during the crop growing period

\begin{tabular}{|c|c|c|c|c|c|c|}
\hline \multirow{2}{*}{ Month } & \multicolumn{2}{|c|}{ Temperature $\left({ }^{\circ} \mathrm{C}\right)$} & \multirow{2}{*}{$\begin{array}{l}\text { Relative } \\
\text { humidity }(\%)\end{array}$} & \multirow{2}{*}{$\begin{array}{l}\text { Wind speed } \\
(\mathrm{km} / \mathrm{hr})\end{array}$} & \multirow{2}{*}{$\begin{array}{l}\text { Sunshine } \\
\text { hour }\end{array}$} & \multirow{2}{*}{$\begin{array}{l}\text { Rainfall } \\
(\mathrm{mm})\end{array}$} \\
\hline & $\operatorname{Max}$ & Min & & & & \\
\hline April* & 36.46 & 27.87 & 78 & 21 & 7.55 & 0 \\
\hline May & 33.27 & 31.31 & 80 & 14 & 6.16 & 372 \\
\hline June & 33.91 & 26.46 & 79 & 15 & 5.10 & 134 \\
\hline July & 32.23 & 26.4 & 84 & 14 & 3.12 & 395 \\
\hline August** & 32.65 & 26.72 & 80 & 16 & 4.92 & 37 \\
\hline
\end{tabular}

*mean was calculated from date of sowing to 30 April

**mean was calculated from $1^{\text {st }}$ day to $10^{\text {th }}$ August 

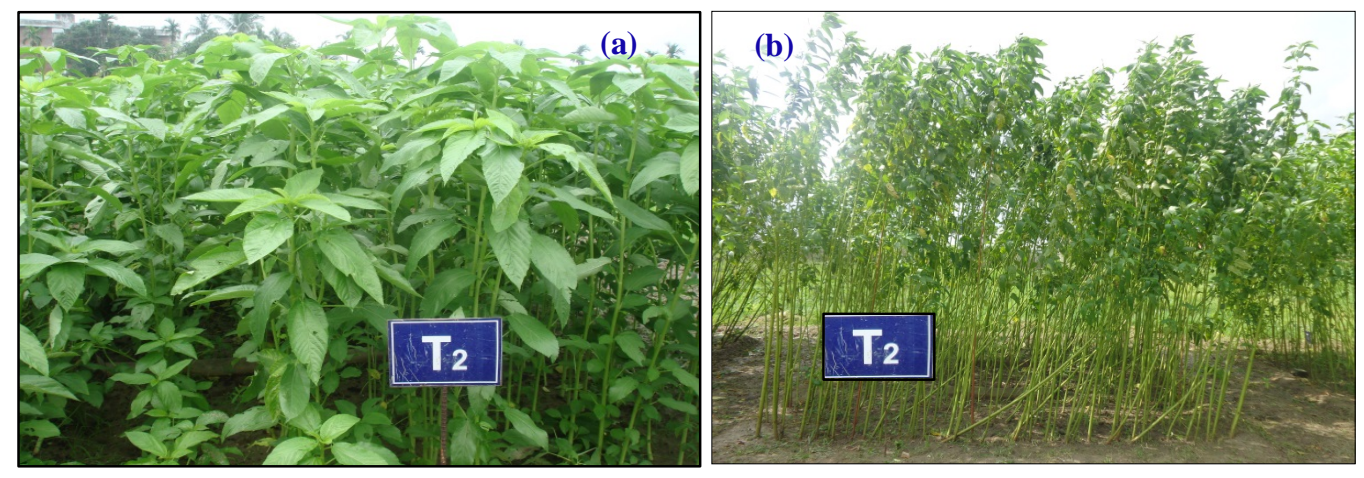

Fig. 1. Photographic view of jute plants under treatment $T_{2}$ grown in the lysimetertank which was surrounded by same crop at the experimental field for creation of favorable atmospheric condition. The age of the plants was 26 days (a) and 98 days (b) at the time of taking the photograph

Recommended fertilizer doses were applied at the rate of $\mathrm{N}_{75}, \mathrm{P}_{12}, \mathrm{~K}_{39}, \mathrm{~S}_{15}, \mathrm{Zn}_{3} \mathrm{~kg} / \mathrm{ha}$, and cowdung of $5 \mathrm{t} / \mathrm{ha}$ (FRG, 2012). Half of $\mathrm{N}$ and total amount of the other fertilizers were applied at the time of final land preparation, and the rest of $\mathrm{N}$ was top dressed at 40-45 days after sowing (DAS) under moist soil condition. Post-sowing irrigation of $112 \mathrm{~mm}$ was applied at 7 and 10 DAS for ensuring proper crop establishment. Intercultural operations (weeding and thinning at 14 and 21 DAS) and pesticide application (Ripcord @1 ppm at 30, 41, 58, 73, 80 and 84 DAS) were applied according to necessity. Irrigation treatment was started at $25 \mathrm{DAS}$ and the crop was harvested on10 August 2016.

The micro-lysimeter in this study contains 4tanks, and it is in fact a one meter square where jute was grown in a condition that is hydrologically separated from the surrounding environment (Michael, 2014). According to Khan et al. (1993), growing crops in such a condition does not need any replication. Similar system was also used by other researchers (Mila et al., 2016a; Mila et al., 2016b) for estimating crop coefficient values of sunflower and soybean at Gazipur. The crop was irrigated according to the following design. Four treatments were used as follows:
$\mathrm{T}_{1}=$ Irrigation at 7 days interval, allowing drainage until receiving the next irrigation

$\mathrm{T}_{2}=$ Irrigation at 14 days interval, allowing drainage until receiving the next irrigation

$\mathrm{T}_{3}=$ Irrigation at 21 days interval, allowing drainage until receiving the next irrigation

$\mathrm{T}_{4}=$ Irrigation at 28 days interval, allowing drainage until receiving the next irrigation

Irrigation was applied more than field capacity to the Lysimeter tank for the assurance of drainage. In addition, the jute plots adjacent to the tanks were also irrigated. Drainage water from the lysimeters was measured by graduated cylinder. The crop evapotranspiration, $\mathrm{ET}_{\mathrm{c}}$, was calculated from the applied irrigation, rainfall and drainage quantities by following water balance equation (Eq. 1) (Itier et al., 1997). Prior to irrigation, soil moisture was measured to determine the depleted soil water during a particular time period. The crop evapotranspiration for the specific period was calculated as:

Crop ET $=\mathrm{W}_{\mathrm{a}}-\left(\mathrm{D}_{\mathrm{w}} \pm \Delta \mathrm{S}_{\mathrm{s}}\right)$

Where, Crop ET is crop evapotranspiration during a specified time period $(\mathrm{mm}), \mathrm{W}_{\mathrm{a}}$ is applied water plus rainfall during the time period $(\mathrm{mm}), \mathrm{D}_{\mathrm{w}}$ is drainage water during the time 
period $(\mathrm{mm})$ and $\Delta \mathrm{Ss}$ is stored soil moisture during the time period $(\mathrm{mm})$.

There are several methods for determining reference evapotranspiration, $\mathrm{ET}_{0}$. Among them, Penman-Monteith method has been recommended for empirical determination of $\mathrm{ET}_{0}$ using climatic data of temperature, humidity, sunshine duration and wind speed (Allen et al., 1998; Michael, 2014). According to Smith et al. (1992), FAO Penman-Monteith method gives more consistent $\mathrm{ET}_{0}$ estimates and has been shown to perform better than other methods. In this study, reference evapotranspiration, $\mathrm{ET}_{0}$, was estimated by using CROPWAT software that uses Penman-Monteith model to calculate $\mathrm{ET}_{0}$. This model requires only insertion of location (latitude, longitude and elevation), and climate data (maximum and minimum air temperature, humidity, sunshine hour and wind speed).

The crop coefficient, $\mathrm{K}_{\mathrm{c}}$ for different growth stages was estimated by using the following formula:

$\mathrm{ET}_{\mathrm{c}}=\mathrm{K}_{\mathrm{c}} \times \mathrm{ET}_{0}$

The internationally recognized crop growth stages for the calculation of crop coefficients are initial, development, mid-season and late season stages (Allen et al., 1998). The duration of each stage depends on the length of growing season of a particular crop and climate (Doorenbos and Pruitt, 1977; Smith et al., 1992). In this experiment, the duration of crop with respect to different growth stages is provided in Table 4.

After 112 days of sowing, plant population, plant height, and base diameter of jute crop were collected. After harvest, data on green weight with leaves $/ \mathrm{m}^{2}$ was collected. The plants were staked in a shady place to remove the leaves. The bundle of green stem was kept under water for rotting. It required 12 days to complete the rotten process. The fiber was then detached from the rotten stem and dried in sun. The data on dry fiber and stalk $/ \mathrm{m}^{2}$ were recorded.

\section{Results and Discussion}

\subsection{Irrigation effect on growth and yield}

The growth, yield and yield contributing parameters of jute variety BJRI Tosa-2 (O-9897) for various irrigation treatments are listed in Table 2. Treatment $\mathrm{T}_{2}$ (irrigation at 14 days interval) produced the highest plant height, base diameter, green weight with leaves $/ \mathrm{m}^{2}$, dry fiber and dry stalk $/ \mathrm{m}^{2}$ in comparison to the other three treatments. This treatment received 7 irrigations whereas $T_{1}$ (irrigation at 7 days interval) received 13 irrigations. This was due to the fact that treatment $T_{2}$, took maximum 7 to 10 days to get completely drainage and rest of days (4-7 days) its root zone was becoming dry prior to receiving next irrigation. This interval seems much more favorable for plant growth and yield followed by treatment $\mathrm{T}_{1}$ (irrigation at 7 days interval). On the other hand, watering at 28 days interval (treatment $\mathrm{T}_{4}$ ) seems too long to provide adequate moisture to plants for normal growth and yield of fiber. There might have some sorts of water stress in the tank that affected crop growth and fiber yield. Consequently, the lowest dry fiber yield was obtained in $\mathrm{T}_{4}$ followed by $\mathrm{T}_{3}$ (irrigation at 21days interval) that produced the lowest green weight with leaves and dry stalk yield among all treatments.

Doorenbos and Pruitt (1977) suggested for calculating the crop coefficients at different growth stages by considering the best growing plants producing the highest yield. Therefore, treatment $\mathrm{T}_{2} \mathrm{was}$ selected for determining the crop co-efficient values in this study. It was noted that the soil moisture fluctuation for different treatments during the growth period was not so high since every treatment received the same amount of rainfall $(938 \mathrm{~mm})$ during the crop season (Figure 2). In treatment $\mathrm{T}_{1}, \mathrm{~T}_{2}$ and $\mathrm{T}_{3}$, soil moisture sometimes exceeded the field capacity due to high rainfall. In treatment $\mathrm{T}_{4}$, soil moisture was within the limit of available moisture due to higher irrigation interval than the other treatments. 
Table 2. Effect of irrigation on growth, yield and yield contributing parameters of jute

\begin{tabular}{lcccccc}
\hline Treatments & $\begin{array}{c}\text { Plant } \\
\text { population }\end{array}$ & $\begin{array}{c}\text { Plant } \\
\text { height } \\
(\mathrm{m})\end{array}$ & $\begin{array}{c}\text { Base } \\
\text { diameter } \\
(\mathrm{mm})\end{array}$ & $\begin{array}{c}\text { Green } \\
\text { weight with } \\
\text { leaves }(\mathrm{t} / \mathrm{ha})\end{array}$ & $\begin{array}{c}\text { Dry fiber } \\
\text { yield } \\
(\mathrm{t} / \mathrm{ha})\end{array}$ & $\begin{array}{c}\text { Dry stalk } \\
\text { yield } \\
(\mathrm{t} / \mathrm{ha})\end{array}$ \\
\hline $\mathrm{T}_{1}$ & 17 & 3.49 & 21.6 & 77.5 & 3.31 & 11.81 \\
$\mathrm{~T}_{2}$ & 21 & 3.62 & 22.3 & 78 & 3.93 & 11.94 \\
$\mathrm{~T}_{3}$ & 18 & 3.35 & 20.2 & 61 & 2.75 & 6.92 \\
$\mathrm{~T}_{4}$ & 16 & 3.33 & 21.6 & 68 & 2.6 & 7.4 \\
\hline
\end{tabular}

Table 3. Seasonal water use or Seasonal ET of jute for treatment $T_{2}$ grown in the lysimeter tank

\begin{tabular}{lccccc}
\hline $\begin{array}{l}\text { Days after } \\
\text { sowing }\end{array}$ & $\begin{array}{c}\text { Irrigation } \\
(\mathrm{mm})\end{array}$ & $\begin{array}{c}\text { Rainfall } \\
(\mathrm{mm})\end{array}$ & $\begin{array}{c}\text { Drainage* } \\
(\mathrm{mm})\end{array}$ & $\begin{array}{c}\text { Stored soil } \\
\text { moisture, } * * \Delta \text { Ss }(\mathrm{mm})\end{array}$ & Crop ET $(\mathrm{mm})$ \\
\hline 25 & 70 & 206 & 180.00 & 5.724 & 101.72 \\
39 & 0 & 182 & 94.00 & -7.86 & 80.48 \\
53 & 50 & 87 & 42.5 & 3.312 & 97.81 \\
67 & 80 & 144 & 145.26 & 16.01 & 94.75 \\
81 & 0 & 148 & 65.35 & -10.44 & 72.21 \\
95 & 0 & 223 & 172.97 & 13.58 & 63.61 \\
109 & 40 & 24 & 20 & -5.46 & 38.54 \\
Seasonal water use & & & & 549.13 \\
\hline
\end{tabular}

* Drainage was calculated by collecting volume of water after irrigation application.

**Stored soil moisture was calculated by subtracting before and after irrigation moisture at the tank.
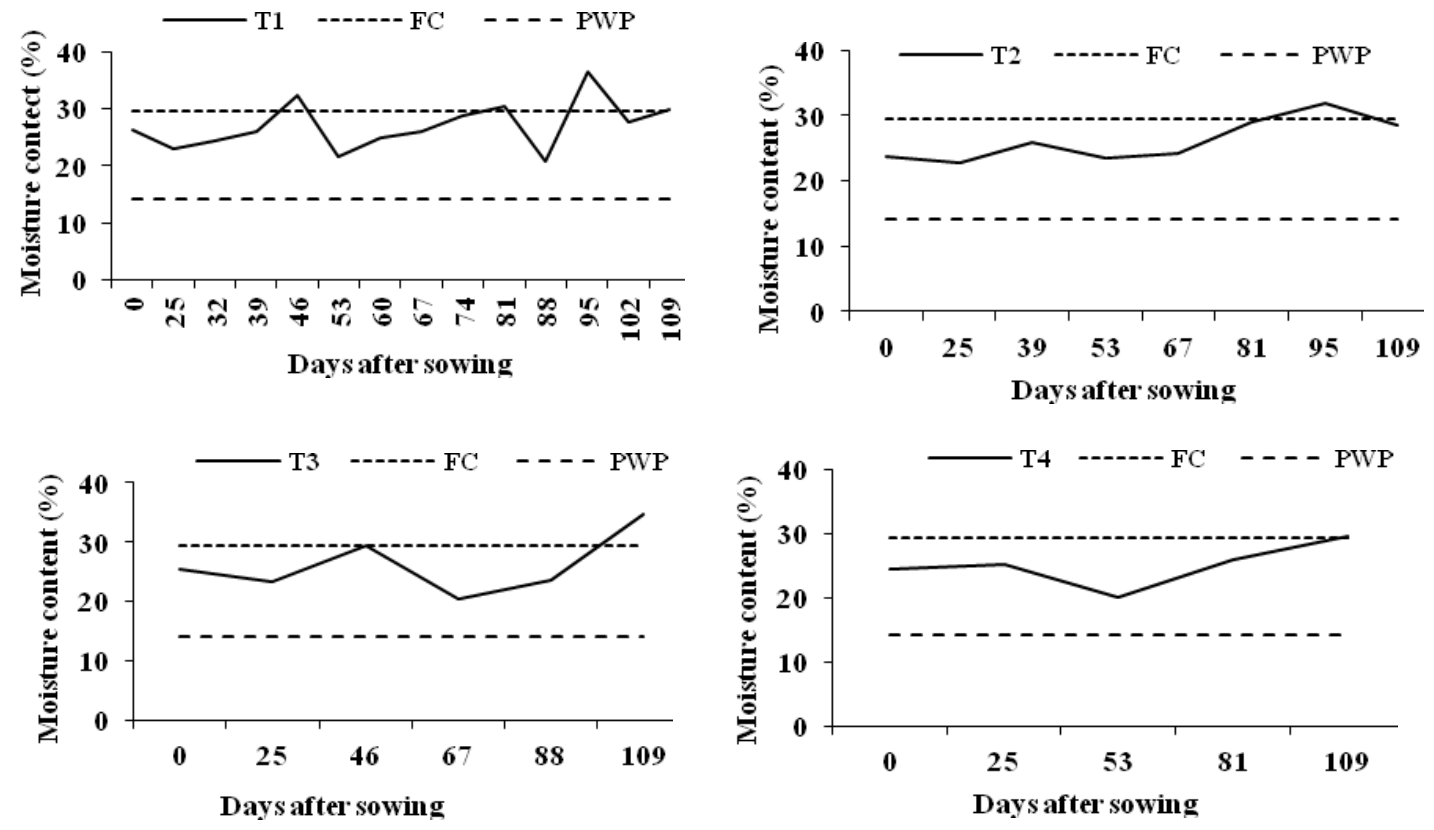

Fig. 2. Soil-moisture content under different treatments during the crop period 


\subsection{Seasonal water use}

Table 3 represents irrigation, rainfall, soil moisture andcrop evapotranspiration values of treatment $T_{2}$ where irrigation interval was 14 days. Irrigation was started from 25 DAS until 109 DAS by maintaining irrigation interval of 14 days. No irrigation was applied at 39, 81 and 95 DAS due to heavy rainfall before these days. The crop was harvested after 6 days of last irrigation. Total evapotranspiration during the crop period was $549.13 \mathrm{~mm}$. The negative soil moisture storageindicates that the plants extracted water from the initial soil moisture content. By contrast, the positive sign indicates that more water was stored in soil in excess of initial water content.

\subsection{Crop coefficient, $K_{c}$}

Evapotranspiration $\left(\mathrm{ET}_{\mathrm{c}}\right.$ and $\left.\mathrm{ET}_{0}\right)$ and crop coefficient vary according to the crop growth stages (Figure 3 to 4 ). At the initial stage, $\mathrm{ET}_{\mathrm{c}}$ was $2.45 \mathrm{~mm} /$ day. It fluctuated and reached the peak value of $10.89 \mathrm{~mm} /$ day at $48 \mathrm{DAS}$, after which it sharply fell to $9.10 \mathrm{~mm} /$ day. On the other hand, $\mathrm{ET}_{\mathrm{o}}$ values fluctuated within the range of 2.35 to $8.55 \mathrm{~mm} /$ day. At the primary stage, $\mathrm{ET}_{0} \mathrm{was} 3.40 \mathrm{~mm} /$ day which gradually fell during the mid-season, and again rose up to 6.48 $\mathrm{mm} /$ day till the period of harvest (Figure 3 ). Table 4 shows crop evapotranspiration $\left(\mathrm{ET}_{\mathrm{c}}\right)$ and reference crop evapotranspiration $\left(\mathrm{ET}_{0}\right)$ value different growth stages. Finally, $\mathrm{K}_{\mathrm{c}}$ values were found to be $0.72,1.39,1.26$ and 0.46 at the four consecutive growth stages. These are the first reported values of crop coefficients for jute in Bangladesh. These values indicate how water requirement of jute needs to be distributed across the growth season. Therefore, based on $\mathrm{K}_{\mathrm{c}}$ value, tabulated $\mathrm{ET}_{\mathrm{c}}$ values for different growth stages can be considered for the irrigation amount of this crop.

Table 4. Crop co-efficient values of jute

\begin{tabular}{llccc}
\hline $\begin{array}{l}\text { Crop growth } \\
\text { stages }\end{array}$ & Duration (Days) & $* \mathrm{ET}_{\mathrm{c}}(\mathrm{mm})$ & $\mathrm{ET}_{0}(\mathrm{~mm})$ & $\mathrm{K}_{\mathrm{c}}$ \\
\hline Initial & $25(1-25$ days after sowing) & 141.05 & 101.56 & 0.72 \\
Development & 31 (26-56 days after sowing) & 142.57 & 198.88 & 1.39 \\
Mid-season & 39 (57-95 days after sowing) & 167.34 & 210.13 & 1.26 \\
Late season & 20 (96-115 days after sowing) & 84.30 & 38.78 & 0.46 \\
\hline
\end{tabular}

*Irrigation amount of jute for different growth stages will be equal to the $\mathrm{ET}_{\mathrm{c}}$ of different growth stages.

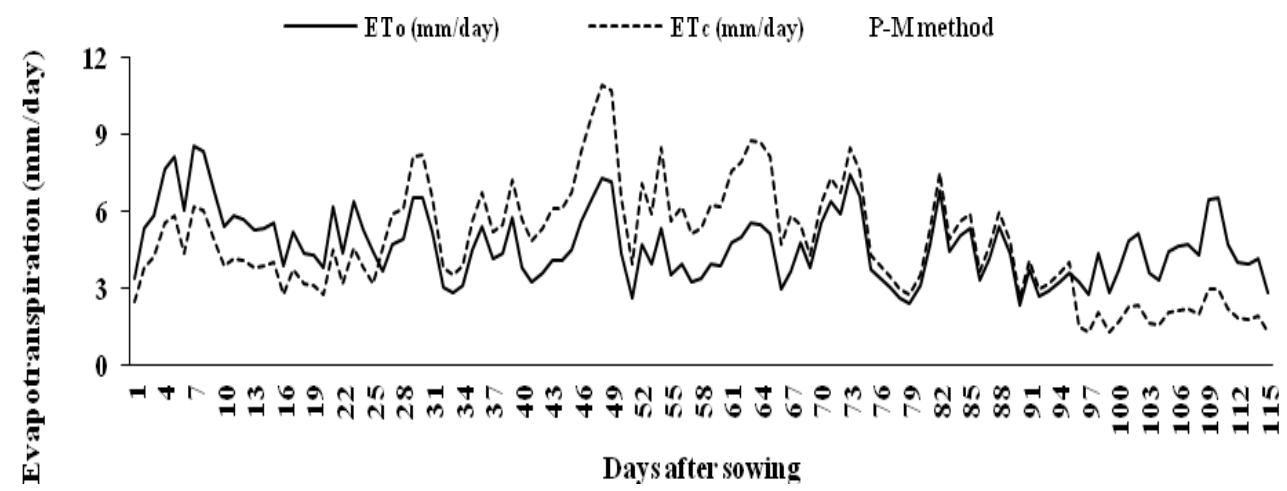

Figure 3. Cropevapotranspiration $\left(\mathrm{ET}_{\mathrm{c}}\right)$ of jute and reference evapotranspiration $\left(\mathrm{ET}_{0}\right)$ during the growing period of jute 


\section{Conclusions}

Seasonal crop evapotranspiration and crop coefficient values of jute was carried out by doing an experiment on Lysimeter at the research field of Irrigation and Water Management Division, Bangladesh Agricultural Research Institute, Gazipur. Result showed that irrigation at 14 days interval, including drainage within two consecutive irrigations, gave the highest yield of jute in this semi-arid region. Seasonal crop evapotranspiration of jute was $549.13 \mathrm{~mm}$ when irrigation was provided at 14 days interval. The crop coefficient values of jute (O9897) were $0.72,1.39,1.26$ and 0.46 at the initial, development, mid-season and late season stages, respectively. These locally calibrated crop co-efficient values can be used reliable information for planning and distribution of regional water resources for irrigation manager. Therefore, based on $K_{c}$ value, it can be recommended that jute can be irrigated by $141.05,142.57,167.34$, and $84.30 \mathrm{~mm}$ of water at the initial, development, mid-season and late season stages to get maximum dry fiber yield.

\section{References}

Alam, M.M., Ahmad, S.A., Khan, A.H. and Hoque, S., 2011. Nutrient uptake, harvest and addition by crops under different cropping sequences. Dhaka University Journal of Biological Sciences, 20(1): 8189.

Allen, R.G., Pereira, L.S., Raes, D. and Smith, M. 1998. Crop evapotranspiration: guidelines for computing crop water requirements. FAO Irrigation and Drainage Paper, 56, Food and Agriculture Organization of the United Nations, Rome, 300 pp.

BBS. 2014. Yearbook of Agricultural Statistics. Bangladesh Bureau of Statistics. Statistics and Information Division. Ministry of Planning.

Begum, T. and Kumar, D., 2014.Breeding for premature flowering resistant lines with improved fibre yield and quality in tossa jute (Corchorus olitorius L.). Bangladesh Journal of Botany, 43(1):9-17.

Billah, M., Sikder, B., Latif, M.A. and Chowdhury, A.K., 2016. Stability Analysis of Selected Jute (Corchorus capsularis L.) Genotypes in Saline and Non-saline Soils of Bangladesh. The Agriculturists, 13(2): 25-35.

Burman, R.D., Nixon, P.R. Wright, J.L. and Pruitt, W.O. 1980.Water requirements. In: Design and Operation of Farm Irrigation Systems, (ed.) M. E. Jensen, St. Joseph, Mich, Transaction of American Society of Agricultural Engineers,189 -232 pp.

Doorenbos, J. and Pruitt, W.O. 1977. Guidelines for predicting crop water requirements; FAO Irrigation and Drainage Paper No. 24. FAO, Rome, Italy.

Fasinmirin, J.T. and Olufayo, A.A. 2009. Yield and water use efficiency of jute mallow Corchorus olitorius under varying soil water management strategies. Journal of Medicinal Plants Research, 3(4):186-191.

FRG. 2012. Fertilizer Recommendation Guide, Bangladesh Agricultural Research Council, Farmgate, Dhaka-1215, 106 pp. www.barc.gov.bd

Islam, S. M. A. Hossain, I.Fakir, G. A. and Asad-Ud-Doullah, M. 2001.Effect of physical seed sorting, seed treatment with garlic extract and vitavax 200 on seed borne fungal flora and seed yield of jute (Corchorus capsularis L.). Pakistan Journal of Biological Science, 4(12):1509-1511.

Itier, B., Brisson, N., Doussan, C. and Tournebize, R. 1997. Bilanhydriqueen Agrometeorologie. Du Couvert Vegetal ala Region, INRA, Versailles, 383 397pp.

Jensen M. (Ed.).1974.Consumptive use of water and irrigation requirements. Rep. Tech.Com. On Irrigation Water Requirements. Irrigation and Drainage 
Division, American Society of Civil Engineers, 227pp.

Khan, B.R., Mainuddin, M. and Molla, M.N. 1993. Design, construction and testing of a lysimeter for a study of evapotranspiration of different crops. Agricultural Water Management, 23:183197.

Michael, A.M. 2014. Water requirement of crops and irrigation management. In: Irrigation Theory and Practice, ( $2^{\text {nd }}$ ed.), India, Vikas Publishing House, 478-553 pp.

Mila, A.J., Akanda, A.R., Biswas, S.K. and Ali, M.H. 2016a. Crop Co-efficient Values of Sunflower for Different Growth Stages by LysimeterStudy. British Journal of Environment and Climate Change, 6(1):53-63.

Mila, A.J., Akanda, A.R. and Sarkar, K.K. 2016b. Determination of crop co-efficient values of soybean (Glycine max [L.] Merrill) by Lysimeter Study. The Agriculturists, 14(2):14-23.

Nizam, M.U., Zaman, M.W., Rahman, M.M. and Hossain, M.H., 2015. Germination Potential of Jute, Kenaf and Mesta to Chromium Toxicity. Journal of Environmental Science and Natural Resources, 8(1):51-57.
Ogunrinde, A.T. and Fasinmirin, J.T. 2012. Soil Moisture Distribution Pattern and Yield of Jute Mallow (Corchorus olitorius) under Three Different Soil Fertility Management. Proc. of the COLERM, 5 Apr 2012, 2: 372-380.

Pruitt, W., Lourence, F.J. and von Oettingen, S.1972. Water use by crops as affected by climate and plant factors. Californian Agriculture, 26(10):10 - 14.

Pruitt, W.O., Fereres, E., Kaita, K. and Snyder, R.L. 1987. Reference evapotranspiration $\left(\mathrm{ET}_{\mathrm{o}}\right)$ for California. Agriculture and Experiment Station Bulletin 1922. University of California, $16 \mathrm{pp}$ and 12 maps.

Smith, M., Allen, R., Monteith, J.L., Perrier, A., Santos Pereira, L. and Sageren, A. 1992. Expert consultation on revision of FAO methodologies for crop water requirements. Food and Agriculture Organization of the United Nations, Land and Water Development Division, Rome, Italy, $60 \mathrm{pp}$.

Tyagi, N.K., Sharma, D.K. and Luthra, S.K. 2000. Determination of evapotranspiration and crop coefficients of rice and soybean with lysimeter. Agricultural Water Management, 45:41-54. 